研究も価值がある.

水素はほとんどが天然ガスから製造されているが，製造コ ストが高いことから水素燃料経済がまだ成立していない，日 本では電気代も高いことから，水の電気分解による製造方式 でも安くなることはないため，低コスト水素製造方式の実用 化ニーズが高い。この技術も将来的には世界標準のひとつと して成長する可能性が高いために，同様に国家産業技術戦略 の開発課題に盛り込まれている.

自動車用 FC の実用化は家庭用電力源としての普及も促進 することから，そのビジネスが注目されている。本来ならば， 家庭用から自動車用へと発展させるのが常道であろうが, 現 状の開発の勢いはむしろ逆方向で進んでいる感がある。よっ て自動車用途の技術確立の目処がたてば，家庭用は相対的に やさしく，それだけ普及する可能性が大きくなる。それだけ に燃料電池技術の研究開発は社会的にも極めて重要なテーマ となっており，電気化学の活躍の大舞台として繰り広げられ ている。

\section{5 おわりに}

21 世紀の自動車は新しいエネルギーパラダイムの実現に よる変革を遂げ，環境負荷低減と脱化石燃料による再生可能 な循環型社会を築き上げながら，一方では家庭用エネルギー システムとも連動した共通インフラをもたらす可能性が高い。 そして冒頭にも述べたように自動車は単なる移動システムで はなく，高度情報通信システムを実現するメディアとしても 発展し，生活空間と機能が一層拡大していく.

しかしながらこのような新分野を開拓していくための研究
開発課題は，広範囲であると同時にハードルが極めて高い。 そしてその中枢をなすのが電気化学であり，これにかかわる 研究者と技術者に多くが託されている，基礎から応用に至る まで，電気化学領域のブレークスルーが循環型社会の実現を 可能にするキーテクノロジーである.

\section{文 献}

1）自動車産業技術戦略策定委員編，国家産業技術戦略一自動車 産業技術戦略, 2000 年 4 月.

2）佐藤 登, 自動車と環境の化学, 大成社, p. 153 (1995).

3) N. Sato, "Decisions, decisions", Electric \& Hybrid Vehicle Technology International '99, 16 (1999).

4) N. Sato, "Electric Vehicle in Earth Environment and Advanced Battery Technology", FISITA 50th Anniversary Congress, F98 T/P068, Invited Lecture, Paris, Sep. 1998.

5) N. Sato, "Heat Behavior Analysis of Nickel Metal Hydride Batteries for Electric Vehicles", J. Advanced Science, 10 (4), 232 (1998), (in Japanese).

6) N. Maruno, K. Araki, and N. Sato, "Thermal Behavior Mechanism of Lithium-ion Batteries for Electric and Hybrid Vehicles”, HONDA R \&D Technical Review, 12 (1), 93 (2000), (in Japanese).

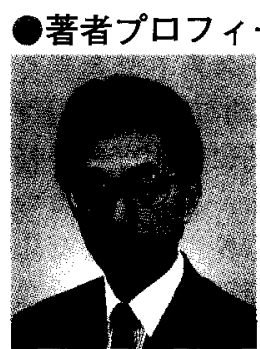

氏名：佐藤 登 Noboru SATO

所属：(株)本田技術研究所杤木研究所( $\bar{\top}$ 321-3393 栃木県芳賀郡芳賀町下高根 沢 4630)

役職：チーフエンジニア

趣味：クラシック音楽，スキー, 野球

\title{
鸟 人に優しい時計作りと二次電池
}

村上 知已

\section{1 はじめに}

まず腕時計の動力源の推移について歴史を紐解いてみる. 腕時計の動力源は，ゼンマイばねのエネルギーから始まる. 指先で竜頭を回転する事でゼンマイばねを巻き上げてエネル ギーを蓄積し，そのゼンマイばねが巻き戻るエネルギーを利 用して，指針の回転動力とした。次に，ゼンマイの巻き上げ 方法を工夫して，腕を振るエネルギーを利用する自動巻時計 へと発展させた。

1960 年代になると，トランジス夕技術の発達，ボタン型 一次電池の開発等の技術開発により，電子式腕時計が発売さ れ，ボタン型一次電池の時代が始まった。さらに，小型水晶 振動子の開発, C-MOSトランジス夕の開発, 高密度 LSI の 開発等の電子技術の発達により, 水晶発振式腕時計の時代と なった．時間精度の飛躍的な向上がなされるとともに，時計 に必要なエネルギーが大幅に減少した。ボタン型一次電池に おいては，より小型の時計にまとめるために，小さいサイズ の電池が開発されてきた。 それによって，男性用の腕時計か ら女性用さらにブレスレットサイズの腕時計まですべての大
きさの腕時計が電子式腕時計となった。

近年になると, 地球環境の急激な悪化に伴いクリーンなエ ネルギーを用いた腕時計の開発が，21 世紀に向けて注目を 浴びるようになってきた。そこで，二次電池の役割は，クり ーンなエネルギーから得たエネルギーを蓄える手段として重 大な役割を果たすものとなってきた。

\section{2 環境に優しい腕時計作り}

クリーンなエネルギーを用いた腕時計として商品化されて いるものには，太陽光等の光エネルギーを用いたもの，腕を 振ることによる運動エネルギーを用いたもの，或いは腕から の体温と周辺温度との温度差による熱エネルギーを用いたも のがある。これらは，人間が時計を腕に装着しているだけで 自然に取得したエネルギーを二次電池に蓄えて使用するもの で，時計の運針及び時間精度を維持するエネルギーを確保で きるようにしている。

今回は，光エネルギーを利用した光発電時計を中心に，話 を進める。 


\section{1 第一世代の光発電時計}

光発電時計の開発の歴史は, 1954 年に単結晶シリコンタ イプのソーラセルが光エネルギーを電気エネルギーへ直接変 換するエレメントとして提案1)されたことに始まる。アモル ファスシリコンソーラセルは, 1977 年に RCA 社から開発報 告された。そのときの変換効率は, 2.4〜 5.5\%2)であった. その他多くのソーラセルの研究開発がなされてきている.

これらのソーラセルを利用した光発電時計として, 単結晶 シリコンソーラセルを用いた腕時計が 1974 年 2 月に発表 ${ }^{3)}$ されたが, 商品として発売されたのは, 1976 年 8 月である. これらに使用された蓄電手段は, 先に発表されたものは二ッ ケルカドミウム二次電池であり, 商品化され発売したものは 酸化銀二次電池であった.アモルファスシリコンソーラセル を用いた腕時計は, 1986 年 5 月に発売された。この蓄電手 段は, キャパシタであり, 持続時間（フル充電状態から光を 当てない状態で時計の運針を維持する時間）は 200 時間, 約 8 日であった。

ここまでに発売された光発電時計は, 驚異的な売れ行きを

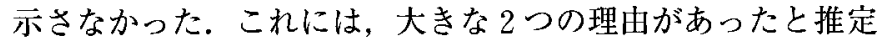
される.

その一つに, 本来の宝飾性を重視する腕時計に対して, ソ 一ラセル自体の色調をもった文字板に限られることである. このことは, いろいろな色調, デザインを具備した文字板を 用いて商品作りをしてきた時計にとって, その商品の幅を狭 くすることである。つまり，幅広く好みの異なる客層に受け 入れられないこととなる. 当時の技術力では, ほぼ全面を覆 う面積にソーラセルを配置して, そのソーラセルの受ける光 エネルギーをほほすずて利用しなければシステム上成り立た なかった。

もう一つは，持続時間が短すぎた点である．これは，一次 電池の腕時計の場合は, 電池寿命は 3 年とか 5 年とか使用者 も認識した上で使用し時計が止まれば電池を交換するという ことで問題なかった，それに対して，光発電時計は自然に腕 に装着していれば，半永久に動き続ける商品への期待が有り， 人によっては，週に 5 日は時計するが，土日は時計を使わな いとか，夏期でも常に長袖を着ているとか様々な生活形態を 考えた場合，それらに対応する技術力に不足があったものと 思われる。

\section{2 光発電時計の基本}

2. 2. 1 エネルギー受給の基本的考え 光発電時計にお いて，時計の消費するエネルギーと携帯中に取得するエネル ギーとの受給のバランスについての基本的考えを説明する.

Fig. 1 は，その基本的考えを説明する図である. Fig. 1 に 示すごとく, 携帯中, 平均的に腕時計が受ける光エネルギー 量（A）は，時計のデザイン性を向上させ，多彩なデザイン の幅を広げるための文字板によって隇衰させられて（B)， その文字板の下部に配置したソーラセルに入力される。ソー ラセルに入力した光エネルギー (C) は，入力に応じた電気 エネルギーに変換され時計の動力源となる。一方, 時計の消 費する消費電力は, 時間の計時を行う回路電力 (D) と, 時 刻表示のための指針を駆動するための駆動電力（E）である. この入力エネルギー量 (C) と消費電力量とが，最低の状態 に拈いてもバランスが取れるようにシステム設計がなされて いる. 工業上のバラッキ等を考虑に入れれば，入力エネルギ 一（C）を多く取得できるように成っている.
2. 2. 2 エネルギー取得量光発電時計で, 最も慎重な 検討を要する事項は, 携帯中の腕時計が取得できる光エネル ギーの予測である。このエネルギーの取得予測を裏付けるた めに, 1 年間の携帯実験を行い, いろいろな人の生活形態に 扔ける光エネルギーの取得量の裏付けデー夕を取得した。

Fig. 2 は，1 1 月毎の取得電力量を月別に表したグラフであ る.この時の時計の条件は, 約 $5.4 \mathrm{~mW} \cdot \mathrm{h}$ の蓄積能力を持 つ二次電池を使用し, 約 $45 \%$ の光透過率の文字板を使用し た時計を用いた。毎の取得電力量とは，1 1 月間携带した 後に蓄積されていた電力と，1 1 月間に消費した電力を加算 した電力量を $100 \%$ の光透過率に変換した電力量である.グ ラフは, 各月の取得電力量の単純な平均値である. 季節によ ってその取得電力の変動が大きいことが分かる.

次に示す Fig. 3 は, 前述の実験に扔ける光発電時計の 2 月 と 8 月の生データである.つまり，1 1 月の携帯後に蓄積さ

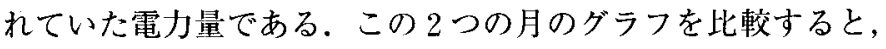
満充電状態の携带者が 8 月に $58 \%$ であったのが，2月には $18 \%$ となっている. 一方, $1.4 \mathrm{~mW} \cdot \mathrm{h}$ 以下のデータがどち らの月においても 10 数\%存在するということを示す。この 10 数\%のデー夕は, 時計の消費電力量とほほ同等以下の取 得電力となる.

2. 2.3 二次電池の役割 Fig. 3 の説明で, 低取得レべ ルの人が，どの月にも 10 数\%存在すると説明した. しかし, このデータの個々を追跡した結果， 1 年間の携帯を通してこ の低レベルを維持する人は, 皆無であった. 1 年間を通して

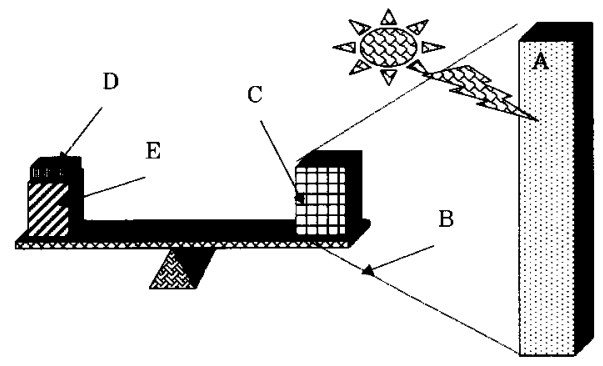

Fig. 1 Image-diagram for solar watch energy-system.

(A) Received energy from Solar-Energy, (B) Received Energy is damped by Color-Filter, (C) Input-Energy of Watch Circuit, (D) Consumed energy by circuit-drive, (E) Consumed energy by motor-drive.

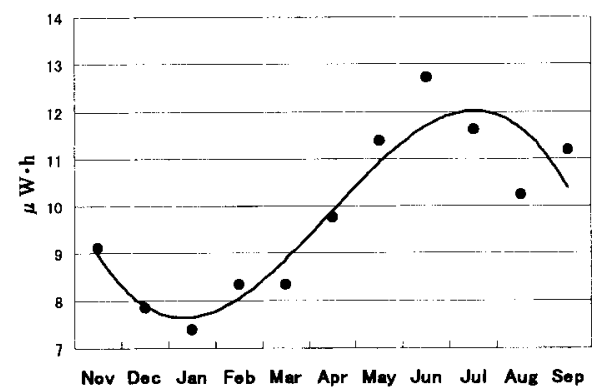

Fig. 2 The change of charged electric capacity for each month.

The charged electric capacity is converted from data by taking the watch of about $45 \%$ transmision rate with one's wrist to data by taking the watch of about $100 \%$ transmision rate. 
見ると時計が消費する以上の電力を取得する月が存在してい る. 個々人の生活の変化から光エネルギーを取得できない期 間が存在するということである。この低取得エネルギー状態 でも安定した時計の駆動を維持するために，二次電池の蓄積 エネルギーが必要となる。

ここで，二次電池にどのくらいの蓄積電力があれば良いか について，検証したものを Fig. 4 に示す.Fig. 4 は，前述の 携帯実験のデータを基に，個々のデータをシミュレーション したものである，初期状態として，その時計の消費電力量に 対して何ヶ月分の蓄積量状態で携带を始めるという想定でシ ミュレーションを行った．その時の時計の停止する人の比率 を検証した．蓄積電力が無い状態 (0ケ月分) で，入力する 光エネルギーのみで時計を駆動すると，11月では $15 \%$ 位の 停止率であるが，夏期になると，その停止率は低下する。こ の検証は，停止しても，そのまま携帯を続けるという実際と は異なる，そこで，初期状態に，1 月月分の蓄積電力を保有 して携帯を始めた場合は，11月中には，初期に蓄積してあ る電力と携帯中に取得しながら蓄積した電力で，12月まで 停止率は $0 \%$ である.しかし，1月になると蓄積した電力で 補うことのできない人が出てくる，このようにして検証して いくと，グラフから 5 ケ月分以上の蓄積能力を持った二次電 池によって，停止率は 1 年間ほとんど $0 \%$ になる。一方，こ の検証では，また光の受けにくくなる冬期を迎える前の 9 月 の末には，5〜6ケ月分の蓄積電力量になっていることも検 証した。

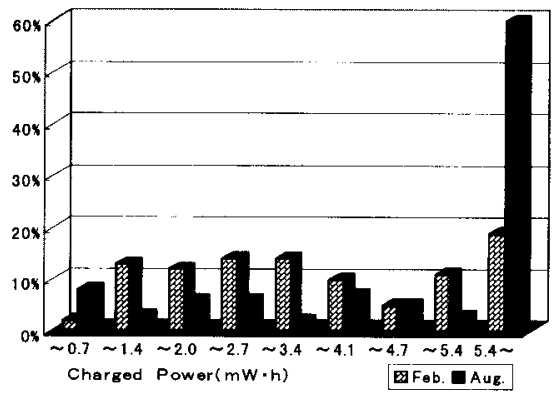

Fig. 3 Histogram of charged capacity in each month after taking the watch with one's wrist during one month.

Max electric capacity of this rechargable battery in the watch is $5.4 \mu \mathrm{W} \cdot \mathrm{h}$.

This histogram is data at Feb. \& Aug..

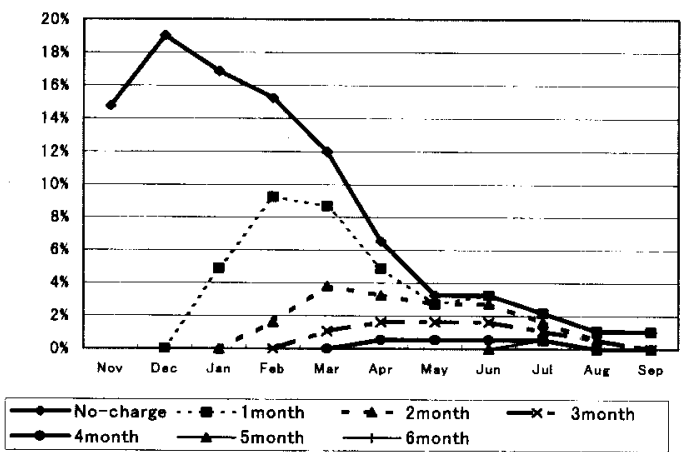

Fig. 4 Stopping-rate for capacity of battery.

Calculated stopping-rate for each capacity on the Field-DATA by taking the watch with one's wrist.
以上のようなエネルギーの受給と蓄積関係の基で光発電時 計は成立している。

\section{3 よりよい商品つくりのための技術開発}

よりよい商品づくりのために，「より白く，より長く，よ り薄く」という指標を設定し，時計システムの改善が行われ た。

「より白く」という指標は，より自由に文字板の色調の選 択幅を持たせることであり，極端なことを言えば従来から使 用している金属製の文字板を使い光発電時計が成り立つよう にしたいところではある．つまり，できるだけ文字板の光透 過率の小さいもので，システム的に成り立つようにすること である. Fig. 1 に示すように光透過率を小さくしてシステム が成り立つためには，時計の消費電力を少なくすることが必 要となる.

「より長く」という指標は，より多くの蓄積能力を持つ二 次電池と時計の消費電力を少なくすることでより長い持続時 間になるシステム作りである。

「より薄く」とは, 時計の商品価值を左右するムーブメン トの厚さと大きさであり，ムーブメントの厚さを薄くするた めに，ソーラセルの厚さ及び二次電池の厚さをできるだけ薄 いものを使用できるシステム構成にすることである。

\section{3.1 消費電力の軽減光発電時計をより良い商品に} 作り上げる最大の課題は，消費電力の軽減である．Fig. 5 は，1996 年から 2000 年までに弊社が開発した光発電時計の 開発時期とその消費電力の推移を表したグラフである。この グラフを見ると，1996 年から 1997 年に開発された時計の全 消費電力は $1.3 \mu \mathrm{W}$ 位である，その内訳は，針を動かすため の運針消費電力が， $1.16 \mu \mathrm{W}$ ，時間精度を制御する回路消費 電力が, $0.14 \mu \mathrm{W}$ である。それが，1999 年から 2000 年にな ると, $0.7 \mu \mathrm{W}$ まで約半減した，その内訳は，運針消費電力 が $0.6 \mu \mathrm{W}$ で, 回路消費電力は $0.1 \mu \mathrm{W}$ であり, 運針消費電 力の低消費電力化の効果が大きい。

2. 3. 2 ソーラセルの対応 ソーラセルにおいては, 近 年における飛躍的な特性の向上はあまりなかったが，アモル ファスシリコン型ソーラを形成する基材の材質と厚さの向上 の効果は大きい. 初期のソーラセルは $700 \mu \mathrm{m}$ のガラス基板 にアモルファスシリコンを形成したものを使用した. 1994 年頃になると, $180 \mu \mathrm{m}$ のステンレス基板上にアモルファス シリコンを形成したものとなり，さらに $150 \mu \mathrm{m}$ のステンレ ス基板上に形成したものが主力をなしている，また，1999

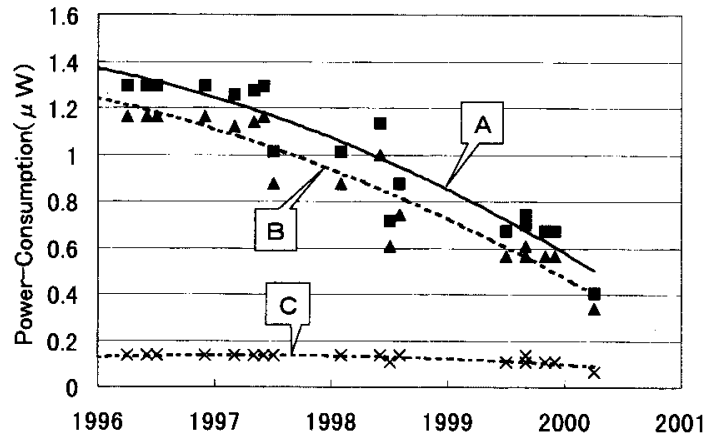

Fig. 5 The change of solar-system watch's power consumption.

A: Total power consumption, B: Power consumption for motor drive, $\mathrm{C}$ : Power consumption for electric circuit drive. 
年には，生産性の向上への期待から $120 \mu \mathrm{m}$ の PET フィル ム上にアモルファスシリコンを形成したフィルムソーラセル を使用するようになった．時計の厚さをできるだけ薄くする ための効果的な推移であり，現在ステンレス基板とフィルム 基板のソーラセルが主体に使用されている。しかし，時計に ソーラセルをより有効に用いるための課題の一つが，取り出 し電極の位置である.限られた表面積の中で効率の良い受光 面を確保する必要である. 取り出し電極が受光面側にあると， 構造上，その電極との接続のため時計の厚さが厚くなり，又 受光面積にも影響する．そこで，取り出し電極を受光面の裏 側に配置することが有効である。この点においては，フィル 么基板を用いることで，電極を受光面の反対側に配置するこ とは容易であり，時計に利用するには，非常に有効である．

\section{3.3 二次電池の動向 二次電池は, 光発電時計を長} 期間安定して駆動させるための電源として，重大な役割を果 たしている，弊社は，前述のごとくキャパシタを蓄電手段と する商品から始めたが，1995 年に $1.5 \mathrm{~V}$ 系コイン型リチウム イオン二次電池が発売されると, すべての光発電時計をこの リチウムイオン二次電池に切り替え, 幅広い光発電時計の商 品作りを行ってきた。これは，リチウムイオン二次電池の蓄 電量がキャパシ夕に比べて大きいためである．しかし，発売 する商品が増えるにつれて，前述のごとく，短い持続時間の 時計は，携帯者の生活状態の要因から，時計が止まるという クレームが増えてきた。そこで, 電池メ一力の協力で容量向 上がなされてきた。それによって，より長い持続時間を有す る商品作りをする事ができた．Fig. 6 は，1.5 V系コイン型 リチウムイオン二次電池のサイズ別容量 UP の推移を示した グラフである。

\section{3 今後の商品作りに向けて}

弊社の開発してきた光発電時計の概況について，話を進め てきたが，今後の環境に優しい時計作りを行っていく上で， どのような技術が必要であろうか?

\section{1 新しい消費電力の削減の考え}

まず，時計システム面からの改善の動きがある．時計は機 械式時計の時代から正確な時刻を表示するために常に動き続 けなければならないという使命があった。しかし，最近では， 使用者が時刻を見られる状態にある時に正確な時刻を表示す る事が重大であり，見ることのない状態（例えば，机の引き 出しの中に放置されているような時）では, 正確な時刻表示 は必要でなく，できるだけ消費する電力を削減しようという 視点に変わってきた。 そこで, 1999 年にSEIKOからキネチ ックオートリレーという商品が発売された。 これは, 使用者 が腕に装着して発電状態にある時は，常に正確な時刻表示を

1. 5V Rechargable Battery

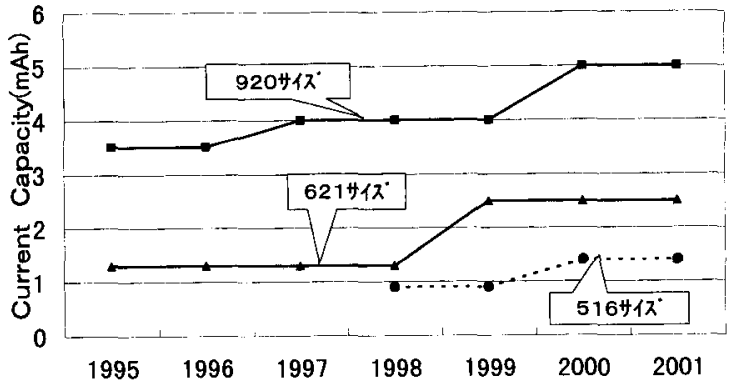

Fig. 6 The change of $1.5 \mathrm{~V}$ rechargable-battery's capacity.
行うが，時計が放置状態，つまり腕の動きによる発電がない 状態が一定時間継続した時に，時刻の計時を行う電子回路シ ステムは動作しているが，指針の運針は行わない，再び発電 状態になると正しい時刻に指針運針を行うというものである。 また，光発電時計においても，光の当たらない状態では，同 様に指針運針は行わなく，光の当たる状態になったら電子回 路の計時情報を基に，正確な時刻表示を行う，要するに，時 計を放置している状態では，最小限のエネルギーで計時する が，多くのエネルギーを必要とする指針運針は行わないとい う考えである。

\section{2 欲しい二次電池}

光発電時計の充実した商品作りが発展できたのには，優れ た特性を持った二次電池の開発と容量の向上によるところが 非常に大きい。現在使用しているコイン型リチウムイオン二 次電池は，100\% 充放電の繰り返しにおいても容量減少等の 特性の劣化が少なく，放電状態においても安定した電圧を維 持できる，という優れた特性である.

少しわがままを言わせていただければ，従来腕時計の商品 つくりは，SR 系の酸化銀電池を主体に行われてきた，SR 系 には中負荷刘応酸化銀電池と重負荷対応酸化銀電池の 2 系統 の電池があり，それらを利用して商品作りを行ってきた．現 有の $1.5 \mathrm{~V}$ 系コイン型リチウムイオン二次電池は, SR 系の 中負荷対応酸化銀電池に匹敵した特性を有している．そこで， 今後商品の幅を広げるためには，重負荷対応の $1.5 \mathrm{~V}$ 系コイ ン型リチウムイオン二次電池が必要になる。

さらに，光発電時計の光エネルギーの取得基準の照度は， 通常に携帯しているときには，500〜数 1000 ルックスを基準 にシステム設計を行っている．しかし，何らかの理由で電池 に急速な充雪が必要になった時, 1 万から 10 万ルックスの 照度下で充電する必要がある. その時, ソーラセルからは $10 \mathrm{~mA}$ 程度の電流で発電されるが, 現有の二次電池では過 大な充電電流に対して，分極状態になり効率の良い充電がで きない.この大電流に対しても効率の良い充電特性を持たせ たい.

\section{4 終わりに}

発電時計を，最低でも 10 年間は支障なく使用できる時計 を目指して開発している。コイン型リチウムイオン電池を使 用しはじめて，まだ 10 年を経過していないが，又 10 年間使 用するためには，時計の構造面でも多くの課題はある。

環境にやさしい時計作りをさらに進展させるためには，よ り優れた二次電池が必要であり，それによってメンテナンス を必要としない時計ができる，電池交換等の時計の修理ので きる施設がないような地域での使用と販売が可能になる。す べての時計を環境に優しい発電タイプのものに置換える事に より，廃棄物を出さない地球環境にやさしい時計を提供でき るものと思っている.

この原稿依頼が来たときには，どうなることかと思ったが， 学会の方々には, 学術的には何ら興味の沸く内容ではないと は思います汸，日頃行っている時計の開発業務内容をまとめ るには良い機会を与えていただいたことに感謝します。

\section{文 献}

1)，2）浜川圭弘，桑野幸徳，太陽エネルギー工学＝太陽電池， 培風館 4 章 (1994)。 
3）日刊工業新聞, 昭和 46 年 (1971), 2 月 14 日.
の著者プロフィール

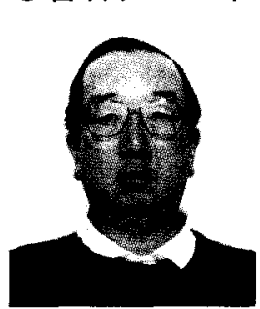

氏名：村上 知巳 Tomomi MURAKAMI 所属：シチズン時計(株) 時計開発部開発推進 課（テ188-8511 田無市本町 6-1-12） 役職：課長

趣味：楽しみゴルフ，旅行等

(ิ) 21世紀の新住宅(燃料電池付の住宅)

\section{1 はじめに}

地球の温暖化を始め森林破壊やオゾン層の減少, 酸性雨, 資源の枯渴など私達を取り巻く環境問題が年々深刻さを増し ている中，住宅レベルにおいても袈境負荷低滅などエコロジ 一, 環境共生という事が重要なテーマとなってきた。現在, 住宅業界では環境共生, 省エネルギーのシンボルとして太陽 電池の住宅への搭載が新エネルギー財団の補助制度を活用し て急速に進められているが，商用電力との系統連系を前提と しており夜間や天候の問題もあり住宅での消費電力の全てを 賄うには無理がある。一方，家庭ではエネルギーを効率的に 使う配慮がそのまま家計に反映するという直結性から省エネ ルギーを実行しやすい場と言える．しかし今日では生活水準 や快適性を落してまでの省エネルギーは現実的とは言えず， これからの省エネルギーの方向は機能性の高い家で快適な生 活をしながら, 同時にエネルギー効率を高めるというもので あろう。そういう意味で, 究極のエネルギーシステムと言わ れる燃料電池こそが，21世紀の住宅にふさわしいエネルギー システムと言え，天候にも左右されず弅夜の区別無く，安定 的に確実に発電し, 給湯・暖房などの熱利用も出来ると言う 理想的なシステムである。ここでは燃料電池の技術的内容に ついては御専門の方々に括せして，住宅メーカーの立場か ら然料電池で 21 世紀の住宅の暮らしがどのように変わるか について述べてみたい。

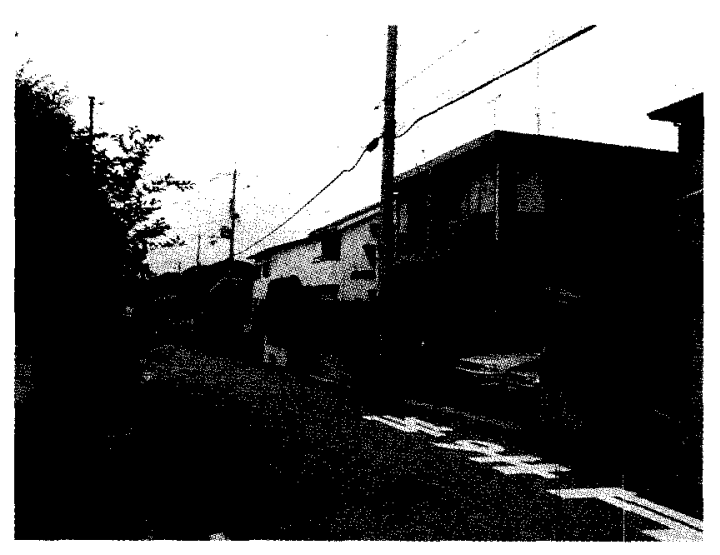

Fig. 1

\section{浅海 広俊}

\section{2 燃料電池が日本の街並みを美しくする}

日本の街並みは欧米と比べると污いと良く言われる. Fig. 1 に示すのは日本の典型的な新興住宅街の写真であるが, 真っ先に目につくのは電柱と張りめぐらせた架空線, そして 道路に描かれた道路標識などである。

一方, Fig. 2 に示すのはあらかじめ景観に配虑して電線類 を地中に理設するなどのランドプランニングがされた，住宅 街の写真である.この 2 枚の写真を見比べてみると, 日本の 街並みが污いと言われる大きな要因の一つが電柱である, と いう事は御理解頂ける事と思う。私が燃料電池の開発に携わ っている方に“燃料電池が日本の街並みを美しくする。” 申し上げると皆さん一様に怪訝な顔をされる。 そこで燃料電 池が各家庭に普及すれば，各家庭が夫々自立して発電する機 能を持っているのだから電柱が要らなくなると, 更に中し上 げると，今度は異口同音に故障したらどうするんですか，答 えが返ってくる. 彼らの考光は万が一故障した時の為に, 商 用電源との系統連系は久かせないと考えているのです。

\section{3 燃料電池はコミニティーで相互に連系して 補完し合えば良い}

燃料電池が日本の各家庭に大量に普及する頃には当然, 自 家用車も燃料電池を搭載したものになっていると思われる. 例えばある 1 軒の家の燃料電池が故障した場合は Fig. 3 の図 に示すように各コミニティーの 10 軒位の単位で相互に連系

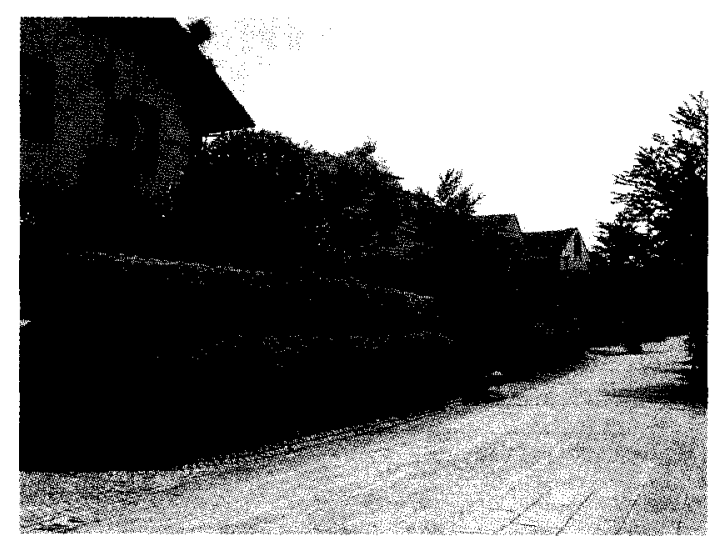

Fig. 2 